Cesur, E. ve Baş, B. (2015) Mavisel Yener'in çocuklara yönelik öykülerindeki eğitsel iletiler üzerine bir araştırma. Ana Dili Eğitimi Dergisi, 3(3), 64-76.

Ana Dili Eğitimi Dergisi
www.anadiliegitimi.com
Gönderilme:01.07.2015 / Kabul Edilme:28.07.2015

\title{
Mavisel Yener'in Çocuklara Yönelik Öykülerindeki Eğitsel İletiler Üzerine Bir
}

\author{
Araştırma* \\ Enise CESUR ${ }^{* *}$ \\ Bayram BAŞ *** $^{* *}$
}

Öz

Eğitimde kazandırılmak istenen değerler öğrenciye çeşitli yollarla verilebilir. Bu yollardan biri de yazınsal değeri olan edebi eserlerdir. Bu bağlamda hikâyeler, eğitsel ileti aktarılması konusunda önem taşıyan edebi türlerden biridir. Hikâyelerde aktarılan iletiler, çocukların kişisel özelliklerinin gelişimine katkı sağlarken, yaşadığı toplumun kültürel öğelerini öğrenmesine ve toplumsallaşma sürecine katılmasına yardımcı olur. Bu düşünceden hareketle araştırmada, Mavisel Yener'in çocuklara yönelik yazdığı hikâyelerindeki eğitsel iletileri tespit etmek ve eğitsel iletilerin sunuluş biçimini ortaya koymak amaçlanmıştır. Yazarın incelenen 75 hikâyesinde yer alan eğitsel iletiler nitel araştırma kapsamında doküman incelemesi yöntemiyle saptanmış ve yorumlanmıştır. Mavisel Yener'in incelenen eserlerinde toplam 592 ileti tespit edilmiş ve bu iletilerin 478'i kişisel gelişimi, 96'sı toplumsal gelişimi, 15'i ulusal gelişimi, 3'ü ise evrensel düşüncenin gelişimini destekler niteliktedir. Çalışma sonuçları gerek eğitimcilerin gerek de ebeveynlerin çocuklar için seçtikleri hikâyelerin, iletiler konusunda nelere dikkat etmeleri gerektiği noktasında rehberlik edecek ve ilkokul düzeyindeki çocukların Mavisel Yener'in hikâyelerinden ne derece faydalanacakları konusunda yardımcı olacaktır.

Anahtar Kelimeler: Illeti, eğitsel ileti, hikâye, Mavisel Yener

\section{A Study On Educational Messages of Mavisel Yener's Children Directed Stories Abstract}

Values that are desired to be granted in education can be given to the student by means of a variety of methods. One of them is using written works that have literary value. In this respect, stories are one of the literary genres that have importance in narrating the educational message. Messages narrated in stories help the children to learn the cultural elements of society and participate in the process of socialization while they are contributing to the characteristics of his/her personality. From this notion, in the study it is aimed to identify the educational messages in the stories of Mavisel Yener and reveal the way of presentation them. The educational messages partaking in 75 stories of the author were identifies and interpreted within the context of qualitative research by means of document review method. A total of 592 messages have been identified within the works of Mavisel Yener and 478 of these messages are such as to support personal development, 96 of them social development, 15 of them national development and 3 of them universal thinking development.

\footnotetext{
* Bu makale Doç. Dr. Bayram Baş danışmanlığında Enise Cesur tarafından hazırlanan "Mavisel Yener'in Çocuklara Yönelik Öykülerindeki Eğitsel İletiler " adlı yayınlanmamış yüksek lisans tezinden özetlenerek üretilmiştir.

** İstanbul Aydın Üniversitesi, Sosyal Bilimler Enstitüsü, Yüksek Lisans Öğrencisi. İstanbul, eposta:enise_ersin@hotmail.com

*** Doç., Dr. Yıldız Teknik Üniversitesi, Eğitim Fakültesi, Türkçe Ana Bilim Dalı. İstanbul, e-posta: bayrambas@gmail.com
} 
The results from this study are going to guide either educators or parents about what aspects they should take care related with the messages of the stories which they chose for their children and help to what extent will the primary school students benefit from the stories of Mavisel Yener.

Key Words: Values education, Educational Message, Story, Mavisel Yener.

\section{Giriş}

Eğitimden beklenen; bilgi ve beceri kazandırma dışında, bireyin kişisel ve toplumsal değerleri tanımasına ve kazanmasına yardımcı olmasıdır. "Değerler, davranışlarımıza yol gösteren, rehberlik eden inançlar ve kurallardır. Eylem ve davranışlarımızın yerindeliğini, etkiliğini, güzelliğini, ahlakiliğini belirlemeye hizmet eden ilke ve standartlardır" (Hökelekli, 2011:285). Gerek davranışlarımızda gerek topluma uyum sağlamamızda bizi aydınlatan en büyük etkenlerdir.

Eğitimde kazandırılmak istenen değerler öğrenciye çeşitli yollarla verilebilir. Bu yollardan biri de yazınsal değeri olan edebi eserlerledir. Aslan’a (2010:49)göre, edebi eserler; "Bir his, duygu coşmasının, bir vecd, yahut bir sevincin, coşkunun verdiği ilhamın eseri olmak dolayısıyla değerler ve maneviyat alanına kategori olarak daha yakındır. Bu bakımdan edebi eserler, değerleri anlatma ve hissettirmede pek çok imkân sunmaktadır"

Edebî eserlerin yazılış amaçlarından en önemlisi ileti (mesaj) aktarmaktır. "Çocuk edebiyatı ürünleri, genellikle çocuğa doğru davranış kalıplarını ve toplum içinde uyulması gerekli kuralları öğretmek; sevgi, saygı, iyilik, dürüstlük, yardımlaşma gibi bir takım değerleri kazandırmak; özetle çocuğu hayata karşı hazırlamak amacı gütmektedir. Bu amaç doğrultusunda yazılan her çocuk edebiyatı ürünü faklı mesajlar içermekte ve çocuğun dünyasında bir yer edinmeye çalışmaktadır" (Arseven, 2005:42).

Latince "communicare" fiilinden gelen iletişim, Nazik ve Bayazit'e göre (2005:97), "Insanlar arasında bilgi, düşünce, anlayış ya da duyguların karşılıklı olarak aktarılması süreci olarak tanımlanabilir"

Babacan'a göre iletişimin amacı, "Zihinler arasında ortak bir algı oluşturmaktır. Her iletişim etkinliğinin bir amacı, iletilmek istenen bir mesajı ve vermek istenen bir hedef kitlesi vardır" olarak açıklamaktadır (2007: 12).

İletişim süreci gönderilen mesajın alıcıya anlaşılır biçimde ulaştırma işlemidir. “iletişim sürecini başlatan kişiye kaynak; kaynaktan alıcıya gönderilen uyarıcılara mesaj; mesajın alıııya iletilmesini sağlayan araç, yöntem ve tekniklere kanal; gönderilen mesaja hedef olan kişiye alıcı; alııının kaynak tarafından gönderilen uyarıcılara verdiği tepkiye dönüt denir" (Ergin ve Birol, 2005:27). Yazınsal iletişimde kaynak yazar, mesaj ileti, kanal yazınsal metinler, alıcı da okurdur.

Yazınsal iletişim öğelerinden olan mesaj (ileti) bu araştırmanın konusu olduğu için derinlemesine incelenecektir. 
Ergin iletiyi, "Mesaj, bir ya da birden fazla kişinin bilişsel, duyuşsal ya da psikomotor davranışlarında değişiklik yapmak amacıyla düzenlenen işaretler örüntüsü“ (2012:43); Özdemir ise iletiyi, yazarın yazma amacı olarak değerlendirmiş ve "Yazarı yazmaya iten başka bir deyişle okuyucusuna vermek istediği ana düşünce, ana duygu" (1983:16)olarak tanımlamıştır.

Sever (2013:140), öğretici metinlerle edebiyat yapıtlarındaki iletinin farklı anlamlar taşıdığını belirtmiştir. "Öğretici metinlerde, yazarın savunduğu, vermek istediği düşünce biçimi; edebiyat yapıtlarındaki ise sanatçının okurlarında yaratmak ya da oluşturmak istediği duygu ve düşünce ortaklığı akla gelmelidir"

Eğitimin amacı çocuklarda olumlu davranış değişikliği kazandırma olduğuna göre çocuk kitaplarının da bu amacı dil, içerik ve anlatım olarak desteklemesi gerekmektedir. Kitaplardaki iletilerin çocuğa sezdirilerek ve bu amaca uygun olarak aktarılması önemlidir.

Çocuklara edebi metinler aracılığıyla aktarılan iletilerin eğitsel olması son derece önemlidir. illetilerde bulunması gereken genel özellikler:

- Iletiler çocuğun bilişsel, duyuşsal gelişim özelliklerine uygun olmalı, çocuğun söz konusu gelişim boyutlarına olumlu katkılarda bulunmalıdır.

- Iletiler ile konu-tema arasında yakın bir ilişkinin olmasına dikkat edilmeli.

- Iletilerin aktarımında önemli bir araç olan konu, dil ve anlatım gibi özellikler, kendi içlerinde bir uyumu barındırmalıdır.

- Iletilerin aktarımında anlatılan metnin özelliği de dikkate alınarak, elden geldiğince zengin bir yola başvurmalıdır. Yani sadece örtük iletiler şeklinde değil, yerine göre doğrudan, dolaylı ve soru şeklindeki iletilerin de metnin içine yedirmiş olmalıdır.

- Iletiler tıpkı tema/ ana fikir gibi eserin yazılma nedeni haline gelebileceği için en az tema/ ana fikir kadar üzerinde ciddi bir biçimde durulmalıdır” (Demirel, Geçen, Seven, Tozlu, Uludağ, 2011:58,59).

- Ileti kavramı ile ilgili diğer önemli husus da iletilerin okuyucuya nasıl aktarılacağıdır.

Sever (2013:140)'e göre, öğretme maksatlı bir kitapla yazınsal nitelikli bir kitabın ileti aktarımın birbirinden farklı olduklarını şöyle ifade etmiştir: “Öğretme amacıyla hazırlanan bir çocuk kitabında temel amaç, çocuklara, öncelikle bilgi aktarmak, onların doğrudan bilgilenmelerini sağlamak; yazınsal nitelikte bir kitabın amacı ise çocukların, sezme, duyma düşünme yetilerini geliştirmek, onlara insana özgü duyarlılıklar kazandırmaktır".

Özdemir de, iletilerin veriliş biçiminin yazı ve yaratılara göre değişiklik göstereceğini şöyle aktarmıştır: "Öğretici boyutlu gazete ve dergi yazılarında ileti önceden saptanmıştır. Konu bu iletiyi somutlayıp yansıtmak için bir araçtır yalnızca. Yazınsal metinlerdeki ileti kesin bir yargıya dönüştürülerek aktarılamaz. Örtük ileti, gizli bir anlam gizli bir öz yükler” (1983: 16). 
Dolaylı ve doğrudan iletileri aktarma şekli, yazarın, edebi yapıtını yazınsal ölçütlere göre yazıp yazmadığını belirleyecektir.

Çocuklara verilebilecek nitelikli eğitimin en temel yapısı onları doğru çocuk yazınlarıyla buluşturmak olacaktır. Yazınsal metinlerde bulunan iletiler üzerine yapılan çalışmalar, yeni yapılacak olan çalışmalara yön vermesi adına önemlidir. Bu doğrultuda çalışmanın amacı, Mavisel Yener'in çocuklara yönelik yazdığı hikâyelerindeki eğitsel iletileri tespit etmek ve eğitsel iletilerin sunuluş biçimini ortaya koymaktır.

Bu çalışmada belirlenen alt problemler şu şekildedir:

1. Mavisel Yener'in hikâyelerinde kişisel gelişimi destekleyen eğitsel iletiler nelerdir?

2. Mavisel Yener'in hikâyelerinde toplumsal gelişimi destekleyen eğitsel iletiler nelerdir?

3. Mavisel Yener'in hikâyelerinde ulusal düşüncenin gelişimini destekleyen eğitsel iletiler nelerdir?

4. Mavisel Yener'in hikâyelerinde evrensel düşüncenin gelişimini destekleyen eğitsel iletiler nelerdir?

5. Mavisel Yener'in hikâyelerinde yer alan eğitsel iletilerin aktarım şekli nasıldır?

\section{Yöntem}

Bu araştırmada nitel araştırma desenlerinden doküman incelemesi kullanılmıştır. Mavisel Yener'in hikâyelerinde yer alan eğitsel iletiler doküman incelemesi yöntemiyle saptanmış ve yorumlanmıştır.

Doküman incelemesi, araştırılması hedeflenen olgu veya olgular hakkında bilgi içeren yazılı materyallerin analizini kapsar. Nitel araştırmada doküman incelemesi tek başına bir veri toplama yöntemi olabileceği gibi diğer veri toplama yöntemleri ile birlikte de kullanılabilir (Yıldırım ve Şimşek, 2013:217).

\section{Araştırmanın İnceleme Nesneleri}

Mavisel Yener'in 7-11 yaş grubu öğrencilerine uygun olan hikâye kitaplarındaki eğitsel iletilerin saptanması amacıyla yapılan bu araştırmanın inceleme nesneleri, 23 tane kitap ve toplam 75 hikâyedir. Araştırmaya sadece Gitme 'Dönmezsin' ve Derin Yırtmaç hikâye kitapları ilkokul öğrencilerinin yaşına uygun olmadıkları için dâhil edilmemiştir.

Tablo.1 Araştırmada kullanılan hikâyeler ve yayınevleri

\begin{tabular}{llll}
\hline S.NO. & KiTAP ADI & ÖYKÜ SAYISI & YAYINEVI \\
\hline 1 & Zeki'nin Zekası Kaçtı & 4 & BILGI YAYINEVI \\
\hline 2 & Kızlar Sünnet Olur Mu? & 9 & BiLGi YAYINEVI \\
\hline 3 & Çikolata Zamanı & 5 & BILGI YAYINEVI \\
\hline 4 & Zaman Torbası & 5 & BiLGI YAYINEVI \\
\hline
\end{tabular}


Tablo.1 (Devamı) Araştırmada kullanılan hikâyeler ve yayınevleri

\begin{tabular}{|c|c|c|c|}
\hline 5 & Hayaletten Mektuplar & 4 & UÇANBALIK YAYINEVI \\
\hline 6 & Üşengeç & 18 & BILGI YAYINEVI \\
\hline 7 & Öğretmen Neden Çıldırdı? & 10 & UÇANBALIK YAYINEVI \\
\hline 8 & Vampir Oyküsü & 5 & BILGI YAYINEVI \\
\hline 9 & Armut Kafa Ailesinin Serüvenleri & & \\
\hline 9.1 & İkizler Okula Başlıyor & 1 & BILGI YAYINEVI \\
\hline 9.2 & Köpekleri Seven Kedi & 1 & BILGI YAYINEVI \\
\hline 9.3 & Papağanlar Ne Yer & 1 & BILGGI YAYINEVI \\
\hline 9.4 & Sihirbaz Dinazor & 1 & BILGI YAYINEVI \\
\hline 9.5 & Piyano Çalan Kedi & 1 & BILGI YAYINEVI \\
\hline 10 & Haylaz Patinin Serüvenleri & & \\
\hline 10.1 & Haylaz Köpek Pati & 1 & TUDEM YAYINEVI \\
\hline 10.2 & Kremalı Köpek Gofreti & 1 & TUDEM YAYINEVI \\
\hline 10.3 & Flüt Çalan Köpek & 1 & TUDEM YAYINEVI \\
\hline 10.4 & Korkunç Gölge & 1 & TUDEM YAYINEVI \\
\hline 10.5 & Öğretmen Sınıfa Ne Getirdi & 1 & TUDEM YAYINEVI \\
\hline 11 & Paylaco Okulu & & \\
\hline 11.1 & Ödevimi Kim Yapar & 1 & BILGI YAYINEVI \\
\hline 11.2 & Unuttum Öğretmenim & 1 & BILGI YAYINEVI \\
\hline 11.3 & Sınıfta Karmaşa & 1 & BILGI YAYINEVI \\
\hline 11.4 & Sınıftaki Aslan & 1 & BILGI YAYINEVI \\
\hline 11.5 & Çantadaki Hazine & 1 & BILGI YAYINEVI \\
\hline
\end{tabular}

Tablo 1'e göre, araştırmada kullanılan hikâye kitaplarının 5 tanesi Tudem Yayınevi'nden, 2 tanesi Uçanbalık Yayınevi'nden ve 16 tanesi de Bilgi Yayınevi'nden elde edilmiştir.

\section{Verilerin Toplanması}

Araştırmanın inceleme nesneleri göre Mavisel Yener'in 23 tane hikâye kitabı Tablo 1'de yer alan ilgili yayınevlerinden temin edilmiştir. Elde edilen dokümanlar yayınevlerinden elde edilmiş ve asıllarının aynısıdır. Herhangi bir şekilde dokümanlar üzerinde oynanmamıştır. Bandrollü olmalarına dikkat edilmiştir. Verilerden çıkarılan kavramlara göre yapılan kodlama sistemi esas alınarak her bir hikâye okunmuş ve incelenmiştir. İnceleme sonucunda tespit edilen eğitsel iletiler bir araya getirilmiş benzerlik ve farklıklarına göre ayrı ayrı gruplanarak kategoriler oluşturulmuştur. Her eğitsel ileti ilgili kategorinin altına işlenmiştir. Yapılan kodlamalar ilgili bölümlerde yorumlanmıştır.

\section{Verilerin Analizi}

Dokümanlar (öykü kitapları) tek başına bu araştırmanın tüm veri setini oluşturmaktadır. Araştırma, Mavisel Yener'in öykülerindeki eğitsel iletileri saptama amacına yönelik olduğu için içerik analizine tabi tutulmuştur. İçerik analizi, "araştırmacı tarafından tanımlanmış araştırma sorusu açısından önem arz eden anlam içerikleri üzerinde odaklaşan bir arama ve tarama stratejisidir" (Gökçe, 2006:17).

Verilerin analizinde içerik analizi tekniklerinden kategorisel içerik analizi kullanılmıştır. Verilerin kodlanmasında, "Verilerden çıkarılan kavramlara göre yapılan kodlama" esas alınmıştır. "Bu tür 
araştırmalarda araştırmacı, verileri satır satır okur ve araştırmanın amacı çerçevesinde önemli olan boyutları saptamaya çalışır. Ortaya çıkan anlama göre araştırmacı, belirli kodlar üretir ya da doğrudan verilerden yola çıkarak kodlar oluşturur (Şimşek ve Yıldırım, 2013:264).

Mavisel Yener'in 23 tane hikâye kitabı, tümevarımcı bir analize tabi tutularak okunmuş ve 56 farklı eğitsel ileti tespit edilmiştir.

Bu iletiler bir araya getirilerek incelenmiş, benzerlik ve farklılıkları doğrultusunda tematik bir kodlama yapılmıştır. Bu tematik kodlama sonucu kategoriler oluşturulmuştur. Kategoriler ve altındaki iletiler uzman görüşüne sunulmuş ve Tablo 2' de gösterilen 4 tane kategori oluşturulmuştur.

Tablo 2. Araştırma verilerine göre oluşturulan kategoriler

\begin{tabular}{l}
\hline Kişisel Gelişimi Destekleyenler \\
\hline Toplumsal Gelişimi Destekleyenler \\
\hline Ulusal Düşüncenin Gelişimini Destekleyenler \\
\hline Evrensel Düşüncenin Gelişimini Destekleyenler \\
\hline
\end{tabular}

Kategoriler veya temalar toplumsal, ulusal, kişilik, evrensel olmak üzere 4 grupta toplanmıştır.

Kategorik kodlamada; kişisel gelişimi destekleyen eğitsel iletilerin her birine "K" harfi, toplumsal gelişimi destekleyen eğitsel iletilerin her birine " $\mathrm{T}$ " harfi, ulusal düşüncenin gelişimini destekleyen eğitsel iletilerin her birine " $U$ " harfi, evrensel düşüncenin gelişimini destekleyen eğitsel iletilerin her birine " $E$ " harfi verilerek kodlama yapılmıştır.

Kodlamada harfler kategori adını, 1'den başlanarak verilen sayılar ise bulundukları kategoriye göre iletilerin sıralamasını göstermektedir. Daha sonra her bir iletinin aktarılma şekline bakılarak doğrudan aktarılan iletiler için " 1 " rakamı ve dolaylı yoldan aktarılan iletiler için " 2 " rakamı kodlamalara eklenmiş ve kodlama tekrar düzenlenmiştir.

Araştırma verilerine göre tespit edilen eğitsel iletiler kategorilere ayrılıp kodlama yapıldıktan ve düzenlendikten sonra aşağıdaki tablolar oluşturulmuştur.

Tablo 3. Kişisel gelişimi destekleyen eğitsel iletilerle ilgili kodlama

\begin{tabular}{llllll}
\hline $\begin{array}{l}\text { ileti } \\
\text { Kodu }\end{array}$ & ileti Adı & $\begin{array}{l}\text { ileti } \\
\text { Kodu }\end{array}$ & ileti Adı & ileti Kodu & ileti Adı \\
\hline K1 & Sorumluluk Almak & K15 & Hayal Gücünü Kullanmak & K29 & $\begin{array}{l}\text { Güvenmek-Güvenilir } \\
\text { Olmak }\end{array}$ \\
\hline K2 & $\begin{array}{l}\text { Alay Etmemek- } \\
\text { Küçümsememek }\end{array}$ & K16 & Vefalı Olmak & K30 & Isşini Severek Yapmak \\
\hline K3 & Tedbirli Olmak & K17 & Sevgiye Değer Vermek & K31 & $\begin{array}{l}\text { Emanete Sahip } \\
\text { Çımak }\end{array}$ \\
\hline K4 & Bencil Olmamak & K18 & Fikirlere Saygı Göstermek & K32 & $\begin{array}{l}\text { Araştırmacı Kişiliğe } \\
\text { Önem vermek }\end{array}$ \\
\hline K5 & Çalışmaya Değer Vermek & K19 & Kararlı Olmak & K33 & $\begin{array}{l}\text { Yaşama Sevinci ile } \\
\text { Dolu Olmak }\end{array}$ \\
\hline K6 & Çözüm Odaklı Düşünmek & K20 & Emeğe Saygı Duymak & K34 & Hoşgörülü Olmak \\
\hline K7 & Ön yargılı Olmamak & K21 & Özgüven Sahibi Olmak & K35 & Azimli Olmak \\
\hline K8 & Sağlı̆ı̆ıı Korumak & K22 & Dikkatli Olmak & K36 & Tutumlu Olmak \\
\hline K9 & Düşünceli Davranmak & K23 & Hatalardan Ders Almak & K37 & Tutarlı Olmak \\
\hline
\end{tabular}


Tablo 3. (Devamı) Kişisel gelişimi destekleyen eğitsel iletilerle ilgili kodlama

\begin{tabular}{llllll}
\hline K10 & Empati Kurmak & K24 & Sabırlı Olmak & K38 & Üşengeç Olmamak \\
\hline K11 & Öfke Kontrolünü Sağlamak & K25 & Temizliğe Önem Vermek & K39 & Soğukkanlı Olmak \\
\hline K12 & Çocuğa Değer Vermek & K26 & Fedakâr Olmak & K40 & Dürüst Olmak \\
\hline K13 & Dostluğa Önem Vermek & K27 & Zamanı Etkin Kullanmak & K41 & Alçak gönüllü Olmak \\
\hline K14 & $\begin{array}{l}\text { Öfke Kontrolünü } \\
\text { Sağlamak }\end{array}$ & K28 & Geçmişe Değer Vermek & & \\
\hline
\end{tabular}

Kişisel gelişimi destekleyen eğitsel ileti kategorisine uygun olan 41çeşit ileti tespit edilmiştir.

Tablo4. Toplumsal gelişimi destekleyen eğitsel iletilerle ilgili kodlama

\begin{tabular}{llll}
\hline ileti Kodu & ileti Adı & ileti Kodu & ileti Adı \\
\hline T1 & Komşuluk iliş̧ilerini Yaşatmak & T2 & Gelenek Görenekleri Yaşatmak \\
\hline T3 & Toplumsal Eşitliği Gözetmek & T4 & Görgü Kurallarına Uymak \\
\hline T5 & Birlik ve Beraberliği Sağlamak & T6 & Yardımsever Olmak \\
\hline T7 & Doğru iletişim Kurmak & T8 & Hakka Saygı Duymak \\
\hline T9 & Misafirperver Olmak & T10 & Yol Gösterici Olmak \\
\hline T11 & Paylaşmak & & \\
\hline
\end{tabular}

Toplumsal gelişimi destekleyen eğitsel ileti kategorisine uygun olan 11 çeşit ileti tespit edilmiştir

Tablo 5. Ulusal düşüncenin gelişimini destekleyen eğitsel iletilerle ilgili kodlama

\begin{tabular}{ll}
\hline Ileti Kodu & İleti Adı \\
\hline U1 & Vatanını Sevmek \\
\hline U2 & Dil Bilincini Oluşturmak \\
\hline U3 & Çevre Bilinci Oluşturmak \\
\hline
\end{tabular}

Ulusal gelişimi destekleyen eğitsel ileti kategorisine uygun olan 2 çeşit ileti tespit edilmiştir.

Tablo 6.Evrensel düşüncenin gelişimini destekleyen eğitsel iletilerle ilgili kodlama

\begin{tabular}{ll}
\hline İleti Kodu & İleti Adı \\
\hline E1 & Barış İçinde Yaşamak \\
\hline
\end{tabular}

Evrensel gelişimi destekleyen eğitsel ileti kategorisine uygun olan 1 çeşit ileti tespit edilmiştir.

Araştırma sürecinde tespit edilen iletiler benzerlik ve farklılıklarına göre tematik bir kodlamayla uygun kategorilere yerleştirilmiş daha sonra bu kategoriler ve altındaki iletiler uzman görüşüne sunulmuştur. Uzman görüşlerinden alınan dönütler doğrultusunda tekrar kategoriler ve altında yer alan iletiler düzenlenmiştir. Çalışmanın inandırıcılığı ve tutarlığı bu şekilde sağlanmıştır.

\section{Bulgular ve Yorum}

Bu bölümde Mavisel Yener'in hikâyelerine yönelik tespit edilen eğitsel iletiler ve bu iletilerin aktarılış şekline dair bulgular verilmiştir. 
Grafik 1. Mavisel Yener'in hikâyelerinde tespit edilen eğitsel iletilerin kullanılma oranları

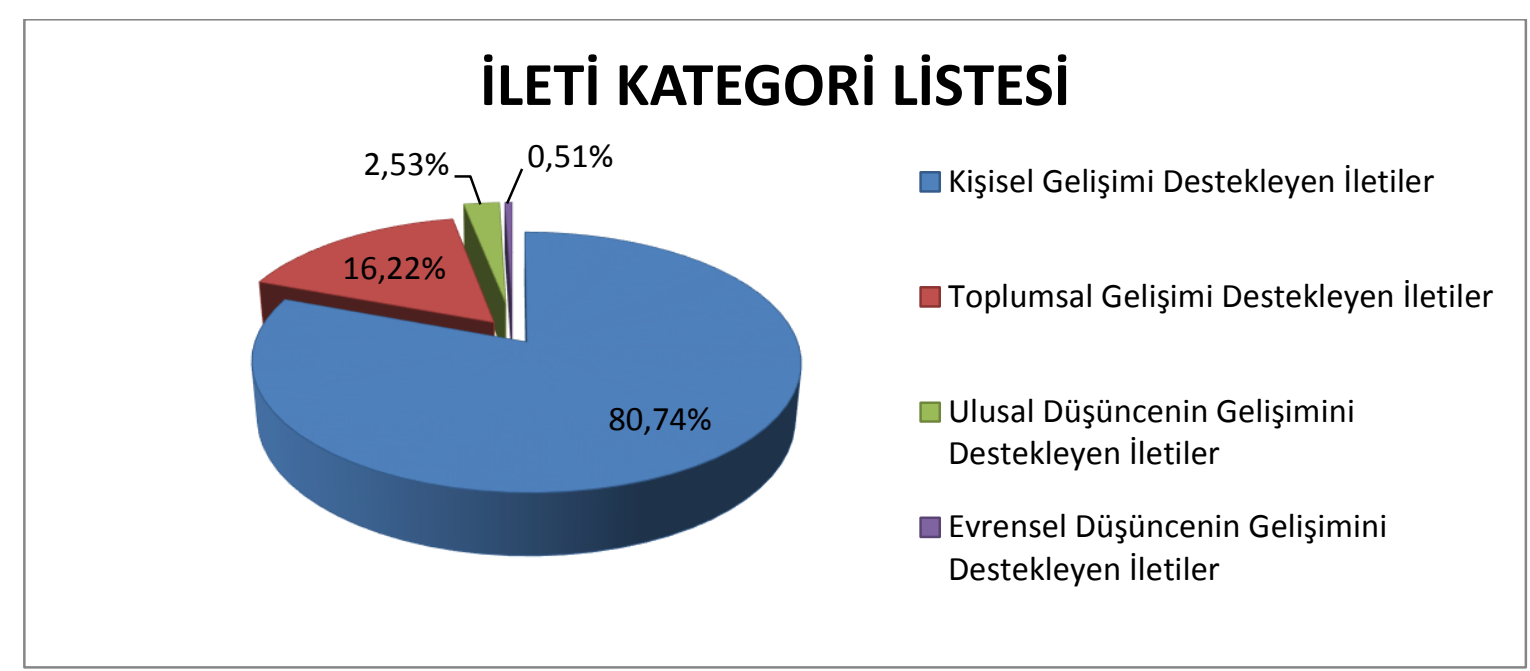

Incelenen hikâyelerde 592 tane eğitsel ileti tespit edilmiştir. Bunların \%80.74'ünü kişisel gelişimi destekleyen ileti, \% 16.22'si toplumsal gelişimi destekleyen ileti, \% 2.53'ü ulusal düşüncenin gelişimini destekleyen ileti ve $\% 0.51^{\prime} i$ evrensel düşüncenin gelişimini destekleyen iletidir.

Tablo 7. Hikâyelerdeki iletilerin sunuluş şekline göre sayıları

\begin{tabular}{ll}
\hline Doğrudan Aktarılanlar & 35 \\
\hline Dolaylı Yoldan Aktarılanlar & $\mathbf{5 5 0}$
\end{tabular}

İncelenen 75 tane hikâyede 35 ileti doğrudan aktarılırken 550 ileti de dolaylı yoldan aktarılmıştır.

Tablo 8. Kişisel gelişimi destekleyen iletilerin kullanım sıklı̆ı

\begin{tabular}{llc}
\hline \multicolumn{1}{c}{ Illeti Adları } & $\mathbf{F}$ & $\%$ \\
\hline Sorumluluk Almak & 55 & $9,29 \%$ \\
\hline Alay Etmemek- Küçümsemek & 14 & $2,36 \%$ \\
\hline Tedbirli Olmak & 28 & $4,73 \%$ \\
\hline Bencil Olmamak & 15 & $2,53 \%$ \\
\hline Çalışmaya Değer Vermek & 5 & $0,84 \%$ \\
\hline Çözüm Odaklı Düşünmek & 14 & $2,36 \%$ \\
\hline Önyargılı Olmamak & 27 & $4,56 \%$ \\
\hline Sağlığını Korumak & 31 & $5,24 \%$ \\
\hline Düşünceli Davranmak & 12 & $2,03 \%$ \\
\hline Empati Kurmak & 21 & $3,55 \%$ \\
\hline Öfke Kontrolünü Sağlamak & 4 & $0,68 \%$ \\
\hline Çocuğa Değer Vermek & 16 & $2,70 \%$ \\
\hline Dostluğa Önem Vermek & 19 & $3,21 \%$ \\
\hline Okumaya Önem Vermek & 25 & $4,22 \%$ \\
\hline Hayal Gücünü Kullanmak & 10 & $1,69 \%$ \\
\hline Vefalı Olmak & 3 & $0,51 \%$ \\
\hline Sevgiye Değer Vermek & 40 & $6,76 \%$ \\
\hline Fikirlere Saygı Göstermek & 6 & $1,01 \%$ \\
\hline
\end{tabular}


Tablo 8. (Devamı) Kişisel gelişimi destekleyen iletilerin kullanım sıklığı

\begin{tabular}{lll}
\hline Kararlı Olmak & 10 & $1,69 \%$ \\
\hline Emeğe Saygı Duymak & 9 & $1,52 \%$ \\
\hline Özgüven Sahibi Olmak & 14 & $2,36 \%$ \\
\hline Dikkatli Olmak & 5 & $0,84 \%$ \\
\hline Hatalardan Ders Almak & 6 & $1,01 \%$ \\
\hline Sabırlı Olmak & 3 & $0,51 \%$ \\
\hline Temizliğe Önem Vermek & 5 & $0,84 \%$ \\
\hline Fedakâr Olmak & 5 & $0,84 \%$ \\
\hline Zamanı Etkin Kullanmak & 4 & $0,68 \%$ \\
\hline Geçmişe Değer Vermek & 2 & $0,34 \%$ \\
\hline Güvenmek-Güvenilir Olmak & 17 & $2,87 \%$ \\
\hline I̧şini Severek Yapmak & 2 & $0,34 \%$ \\
\hline Emanete Sahip Çımak & 3 & $0,51 \%$ \\
\hline Araştırmacı Kişiliğe Önem Vermek & 11 & $1,86 \%$ \\
\hline Yaşama Sevinci ile Dolu Olmak & 6 & $1,01 \%$ \\
\hline Hoşgörülü Olmak & 3 & $0,51 \%$ \\
\hline Azimli Olmak & 3 & $0,51 \%$ \\
\hline Tutarlı Olmak & 1 & $0,17 \%$ \\
\hline Üşengeç Olmamak & 7 & $1,18 \%$ \\
\hline Soğukkanlı Olmak & 3 & $0,51 \%$ \\
\hline Dürüst Olmak & 8 & $1,35 \%$ \\
\hline Alçak Gönüllü Olmak & 1 & $0,17 \%$ \\
\hline Tutumlu Olmak & 5 & $0,84 \%$ \\
\hline TOPLAM & $80,74 \%$ \\
\hline
\end{tabular}

Hikâyelerde en sık kullanılan kişisel gelişimi destekleyen eğitsel iletiler arasında 55 defa kullanılmasıyla "sorumluluk almak" iletisidir. "Sorumluluk almak" iletisi toplam iletilerin \% 9.29'unu meydana getirmiştir. İkinci en sık kullanılan ileti ise 40 sıklıkla "sevgiye değer vermek" iletisidir. Bu ileti toplam iletilerin \% 6.76' sını oluşturur. Hikâyelerde toplam 478 defa kişisel gelişimi destekleyen eğitsel ileti kullanılmış ve bu tüm iletilerin \% 80.74'ünü oluşturmuştur.

Tablo 9. Toplumsal gelişimi destekleyen iletilerin kullanım sıklığı

\begin{tabular}{lll}
\hline ileti Adı & F & \% \\
\hline Komşuluk İlişkileri YaşatmakT1 & 6 & $1,01 \%$ \\
\hline Gelenek Görenekleri Yaşatmak T2 & 9 & $1,52 \%$ \\
\hline Toplumsal Eşitliği GözetmekT3 & 11 & $1,86 \%$ \\
\hline Görgü Kurallarına Uymak T4 & 19 & $3,21 \%$ \\
\hline Birlik ve Beraberliği Sağlamak T5 & 11 & $1,86 \%$ \\
\hline Yol Gösterici Olmak T10 & 4 & $0,68 \%$ \\
\hline Yardımsever Olmak T6 & 5 & $0,84 \%$ \\
\hline Hakka Saygı Duymak T8 & 4 & $0,68 \%$ \\
\hline
\end{tabular}


Tablo 9. (Devamı) Toplumsal gelişimi destekleyen iletilerin kullanım sıklığı

\begin{tabular}{lll}
\hline Misafirperver OlmakT9 & 15 & $2,53 \%$ \\
\hline Doğru iletişim KurmakT7 & 11 & $1,86 \%$ \\
\hline PaylaşmakT11 & 1 & $0,17 \%$ \\
\hline TOPLAM & 96 & $16,22 \%$ \\
\hline
\end{tabular}

Hikâyelerde en sık kullanılan toplumsal gelişimi destekleyen eğitsel iletiler arasında 19 defa kullanılmasıyla "görgü kurallarına uyma" iletisidir. "Görgü kurallarına uyma" iletisi toplam iletilerin \% 3.21'ini oluşturmuştur. íkinci en sık kullanılan toplumsal gelişimi destekleyen ileti ise 15 sıklıkla "misafirperver olmak" iletisidir. Bu ileti toplam iletilerin \% 2.53'ünü oluşturur. Hikâyelerde toplam 96 defa toplumsal gelişimi destekleyen eğitsel iletinin kullanılmış olması tüm iletilerin \%16.22'sini oluşturmuştur.

Tablo 10. Ulusal düşüncenin gelişimini destekleyen iletilerin kullanım sıklı̆ı

\begin{tabular}{lll}
\hline & $\mathbf{F}$ & $\mathbf{\%}$ \\
\hline Vatanını Sevmek & 3 & $0,51 \%$ \\
\hline Dil Bilinci Oluşturmak & 8 & $1,35 \%$ \\
\hline Çevre Bilinci Oluşturmak & 4 & $0,68 \%$ \\
\hline TOPLAM & 15 & $2,53 \%$ \\
\hline
\end{tabular}

Hikâyelerde en sık kullanılan ulusal düşüncenin gelişimini destekleyen eğitsel ileti arasında 8 defa tekrar etmesiyle "dil bilinci oluşturmak" iletisidir. "Dil bilinci oluşturmak" iletisi toplam iletilerin \% 1.35'ini oluşturmuştur. Bu kategorideki iletiler incelenen hikâyelerde 15 defa tekrar etmesiyle tüm iletilerin \% 2.53'ünü oluşturmuştur.

Tablo 11. Evrensel düşüncenin gelişimini destekleyen iletilerin kullanım sıklığı

\begin{tabular}{lll}
\hline & $\mathbf{F}$ & $\mathbf{\%}$ \\
\hline Barış İçinde Yaşamak & 3 & $0,51 \%$ \\
\hline TOPLAM & 3 & $0,51 \%$ \\
\hline GENEL TOPLAM & 592 & $100,00 \%$ \\
\hline
\end{tabular}

Hikâyelerde en sık kullanılan evrensel düşüncenin gelişimini destekleyen eğitsel ileti arasında 3 defa tekrar etmesiyle "barış içinde yaşamak" iletisidir. "Barış içinde yaşamak" iletisi toplam iletilerin $\% 0.51$ 'ini oluşturmaktadır.

Mavisel Yener'in İncelenen hikâye kitaplarında 41 farklı kişisel gelişimi destekleyen ileti, 11 farklı toplumsal gelişimi destekleyen ileti, 3 farklı ulusal düşüncenin gelişimini destekleyen ileti ve 1 çeşit de evrensel düşüncenin gelişimini destekleyen ileti tespit edilmiştir.

Kişisel gelişimi destekleyen iletilerden en sık elli beş defa ile "sorumluluk almak" iletisi tekrarlanırken en az da "alçak gönüllü olmak" ve "tutarlı olmak" iletileri tekrarlanmıştır.

Mavisel Yener'in incelenen eserlerinde kullanılan doksan altı iletiyle, toplumsal gelişimi destekleyen iletiler, kişisel gelişimi destekleyen iletilerden sonra ikinci sıradadır. Çocuğun yaşadığı toplumdaki diğer bireylerle uyumunu kolaylaştıran bu iletilerden en sık kullanılanları şunlardır: 
komşuluk ilişkilerini yaşatmak, gelenek - görenekleri yaşatmak, toplumsal eşitliği gözetmek, misafirperver olmak, doğru iletişim kurmak, hakka saygı duymak, görgü kurallarına uymak.

Incelenen kitaplarda 15 tane ulusal gelişimi destekleyen ileti tespit edilmiştir. Bu kategoride; vatan sevgisi, dil bilinci oluşturma ve çevre bilinci konularında iletiler aktarılmıştır.

Evrensel düşüncenin gelişimi kategorisinde ise barış içinde yaşamak iletisine yer verilmiştir.

\section{Sonuç}

Yazarlar okuyucuya vermek istedikleri mesajları eserleri aracılığıyla aktarmaktadırlar. Kullandıkları iletilerin eğitselliği ve aktarış biçimleri, yazdıkları eserlerin yazınsal niteliklere uygun olup olmadığını gösteren en önemli unsurlardır. Bu nedenle araştırmamızda Mavisel Yener'in çocuklara yönelik yazdığı 23 tane hikâye kitabında yer alan iletilerinin eğitselliği ve aktarılış biçimi incelenmiştir.

Mavisel Yener'in incelenen eserlerinde 592 ileti tespit edilmiş ve bunların 478 tanesini kişisel gelişimi destekleyen eğitsel iletiler oluşturmuştur. Yazarın bu kategorideki iletilere bu denli ağırık vermesindeki amacı, öncelikle kişilerin kendini tanımalarına yardımcı olmak istemesi olarak değerlendirilebilir. Kişisel gelişimi destekleyen iletilerle bireyin çok yönlü gelişmesi hedeflenir. Bireyin kendinde bulunan eksikleri bu iletilerle fark etmesi, çevresiyle de bulunduğu etkileşimin daha sağlıklı olmasını sağlar. Eğitsel iletilerle ilgili yapılan çalışmalarda bazı yazarların da eserlerinde kişisel gelişimi destekleyen iletileri diğer iletilere oranla daha fazla kullandıkları görülmüştür (Gülgönül,2014;Kaplan,2013;Akkaya,2008). Yener'in incelenen hikâyelerinde kişisel gelişimi destekleyen iletiler arasında 55 defa "sorumluluk alma" iletisinin kullanıldığı görülmüştür. Bu ileti, çocuklara, okulda ve evde bazı sorumluluklarının olduğu hatırlatılarak aktarılmıştır. Ebeveynlerin iş hayatlarındaki ve ev yaşamlarındaki sorumlulukları üzerinde durulmuştur. Mavisel Yener hikâyelerinde seçtiği kahramanlar genellikle sorumluluklarının farkında olan tiplerdir. Yazar eserlerinde yine sıkça "sevgiye değer vermek" iletisini kullanmıştır. Bu iletiyle hayvan sevgisi, doğa sevgisi ve insan sevgisi konularını işlemiştir. Özellikle hayvan sevgisi konusunu sıkça işlemesi Yener'in bu konudaki duyarlıığını da ortaya koymaktadır. Sevgi konusunda insan sevgisini, hayvan sevgisini ve tabiat sevgisini ele alan bir başka yazar da Hidayet Karakuş’tur (Kaplan, 2013). "Sağlığını korumak" iletisi ile de çocuklara dengeli ve düzenli beslenme alışkanlığı, diş fırçalama alışkanlığı kazandırma amaçlanmıştır. Yazarın kendisinin aynı zamanda diş hekimi olması hikâyelerinde bu konuyu işlemesinde önemli bir etken olabilir. Yazar hikâyelerinde genellikle okumayı seven, hayal dünyaları geniş, sorunları kendi çözebilen, iletişim yetenekleri güçlü kahramanlar kullanmıştır. Bu özelliklerden dolayı da okuyucu kitlesine de olumlu özellikler aktarmaktadır.

Mavisel Yener, kişisel gelişimi destekleyen iletilerden sonra 96 iletiyle en sık toplumsal gelişimi destekleyen iletileri kullanmıştır. Bilgin Adalı ve Mustafa Kutlu'nun da çocuklara yönelik yazdığı eserlerinde kişisel gelişimi destekleyen iletilerden sonra toplumsal gelişimi destekleyen iletilere ağırlık 
verdiği bu konuyla ilgili yapılan araştırma sonuçlarında görülmüştür (Gülgönül,2014; Akkaya,2008). İnsanlar toplumsal bir varlık olması nedeniyle yaşadığı toplumun değer yargılarına uymak durumundadır. Görgü kuralları da toplumların önemli değerleridir. Yazar "görgü kurallarına" uyma iletisiyle özellikle başkalarını rahatsız etmemeye özen gösterilmesi gerektiği ve yaşıılara saygı konularını işlemiştir. Türk kültüründe misafirperverliğe yüklenen anlam oldukça önemlidir. Yener de hikâyelerinde "misafirperver" olma iletisine değinmiştir. Özellikle misafir ağırlarken her şeyin kusursuz olmasına dikkat eden aileleri konu almıştır. Mavisel Yener, kadın-erkek eşitliğini gözetmek iletisi ile bu eşitliğin sağlanmadığı durumları anlatarak çocuğun çıkarımda bulunmasını amaçlamıştır. Yazar, toplumsal gelişimi destekleyen iletilerde "doğru iletişimi kurmak" iletisinin üzerinde durmuş ve ailelerin çocuklarını iyi anlamaları için onlarla doğru iletişim kurmaları gerektiğini vurgulamıştır.

Ulusal gelişimi destekleyen iletilerde özellikle "dil bilinci oluşturma” iletisi üzerine durmuştur. Bu iletiyle dilimizdeki sözcüklerin anlamlarına uygun kullanılması gerektiği ve yabancı sözcüklerin etkisinden kurtarmanın önemine değinmiştir. Yabancı dilden gelen sözcüklerin günlük hayattaki sohbetlerde kullanımını eleştirdiği ortadadır. Mavisel Yener, hikâyelerinde vatan özlemi çeken kahramanları kullanarak vatan sevgisi iletisini aktarmayı amaçlamaktadır.

Mavisel Yener' in incelenen çocuklara yönelik eserlerinde en az evrensel düşüncenin gelişimini destekleyen ileti bulunmuştur.

Yazar, okuyucusunu güldürerek düşündürmeyi amaçladığından mizahi anlatımı sıkça kullanmıştır. Dili sade ve anlaşılır olmakla birlikte son derece akıcı olmasının sebebi kullandığı sözcüklerin zenginliğinden kaynaklanmaktadır.

Mavisel Yener'in incelenen eserlerinde okuyucunun dikkatini çekmek için “Kızlar Sünnet Olur Mu”, "Zeki'nin Zekâ'sı Kaçtı”, “Hayaletten Mektuplar” gibi başlıkları kullandığı görülmektedir. Yazar, kitaplarında okuyucunun merakını hikâyenin sonuna kadar canlı tutmayı başarabilen çok değişik temalar işlemiştir.

Mavisel Yener hikâyelerinde iletileri satır aralarına gizleyerek dolaylı yoldan aktarmaktadır. Öğretici olmak gibi bir kaygısı olmayan yazar, çocuklarda okuma alışkanlığı kazandırmayı amaçlamaktadır.

Hikâyelerdeki kişilerin gerçek hayattan seçilmesi, olayların herkesin yaşayabileceği türden olması okuyucunun ilgisinin eser üzerinde yoğunlaştırmasını sağlamaktadır.

İncelenen hikâye kitaplarında iletilerin, çocukların yaş seviyesine uygun olduğu görülmekte ve sakıncalı konularda ileti aktarımında bulunulmadığı tespit edilmiştir.

\section{Öneriler}

Mavisel Yener'in bu araştırmada incelenen eserlerinde, aktardığı iletilerin sayı ve çeşitlilik konusunda oldukça zengin olduğu ancak evrensel düşüncenin gelişimini destekleyenin iletilerin diğer 
iletilere oranla daha az kullandığı sonucuna varılmıştır. Bu kategorideki iletilere yazınsal yapıtlarda daha çok yer verilmesi, çocukların evrensel değerlere karşı olumlu tutum geliştirmelerine destek sağlayacaktır.

Öğretici olma gibi bir kaygısı olmayan Yener'in iletileri dolaylı yoldan aktarması okuyucunun bu eserleri zevkle okumasında etkili olacaktır. Yazarın hikâyelerinde genellikle aile içinde geçen olayları işlemesi ve kahramanları gündelik hayattan seçmesi, mizahi bir anlatımı kullanması çocuklarda okuma sevgisi ve okuma alışkanlığı kazandırmada yardımcı olması beklenmektedir.

Çalışma bu konuda yeni yapılacak olan akademik çalışmalara kaynaklık etmesi bakımından önemlidir. Eğitsel iletilerin tespiti ve aktarıcılığı konusunda yapılan akademik çalışmalar gerek ebeveynler gerek de öğretmenler açısından çocuklara yönelik yazınsal nitelikli kitapları tercih etmelerini sağlayabilir. Bu konuda yapılan ve yapılacak olan çalışmalarla, yazarların daha nitelikli kitapları yazmalarına sebep olabileceği gibi ilkokul düzeyinde okutulması gereken kitapları belirleyen kurumlara kaynaklık edebilir. Sınıf öğretmenlerinin de öğrencilere okutulacak olan kitapları önce kendilerinin okuyarak ve iletileri tespit ederek etkinlikler düzenlemeleri, çocukların bu eğitsel iletileri kazanmalarını etkin hale getirebilir.

\section{Kaynakça}

Akkaya, A. (2008). Mustafa Kutlu'nun hikâyelerindeki iletiler ve bu iletilerin çocuğa görelik ilkesi açısından incelenmesi. Elazığ: Fırat Üniversitesi, Yayınlanmış Yüksek Lisans Tezi.

Arseven, T. (2005). Mesaj açısından çocuk kitapları. Hece Dergisi, (104-105), 46-51.

Aslan, Z. Ş. (2010). Değerler eğitiminde bir yöntem önerisi: edebiyat metinlerinden yararlanma. Değerler Eğitimi Konferans Bildirileri (s. 47-55). İstanbul: Damla Yayınevi.

Babacan, Mahmut. (2007). Yazılı ve sözlü anlatım, İstanbul: 3F Yayınevi

Demirel, Ş., Uludağ, M. E., Tozlu, N., Seven , S., ve Çeçen, M. A. (2011). Edebi metinlerle çocuk edebiyatı. Ankara: Pegem Akademi.

Ergin, A. ve Birol, C. (2005). Eğitimde iletişim, Ankara: Anı Yayıncılık

Ergin, A. (2012). Eğitimde etkili iletişim, Ankara: Anı Yayıncılık

Gökçe, O.(2006).İçerik analizi kuramsal ve pratik bilgiler, Ankara: Siyasal Kitabevi

Gülgönül, B. (2014). Bilgin Adalı'nın hikâye ve romanlarında yer alan eğitsel iletiler. İzmir: Dokuz Eylül Üniversitesi, Yayınlanmış Yüksek Lisans Tezi.

Hökelekli, H.(2011). Ailede, okulda, toplumda değerler psikolojisi ve eğitimi. İstanbul: Timaş Yayınları

Kaplan, K. (2013). Hidayet Karakuş'un roman ve hikâyelerinde yer alan eğitsel iletiler. Afyonkarahisar: Afyon Kocatepe Üniversitesi, Yayınlanmış Yüksek Lisans Tezi.

Nazik, H. M. ve Bayazıt, A. (2005). Insan iliş̧kileri ve iletişsim, İstanbul: Ya-pa Yayın Pazarlama

Özdemir, E.(1983). Yazı ve yazınsal türler, İstanbul: Varlık Yayınları

Sever, S. (2013). Çocuk ve edebiyat, Ankara: Tudem Yayınları

Yıldırım, A., ve Şimşek, H. (2013). Sosyal bilimlerde nitel araştırma yöntemleri. Ankara: Seçkin Yayıncılık 